\title{
Determinants of the capital structure of Portuguese firms with investments in Angola
}

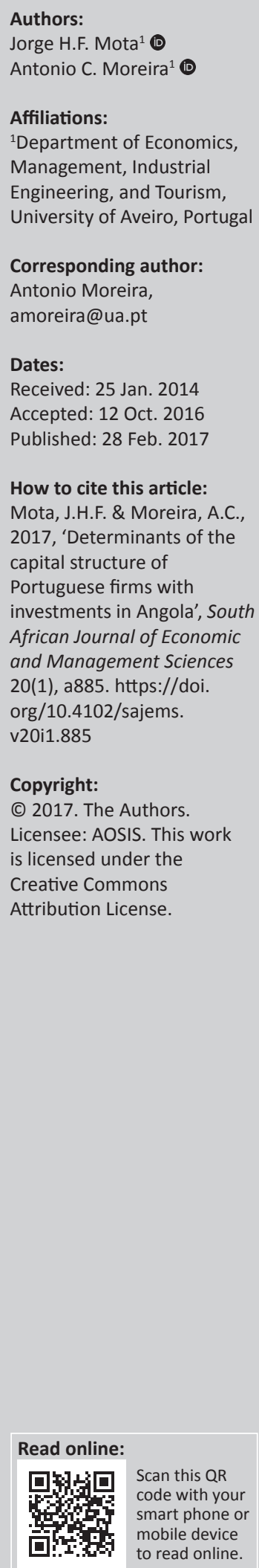

Background: This article seeks to complement the previous literature and clarify the particularities of the capital structure policy of firms with foreign direct investment in Angola.

Aim: This article seeks to identify the determinants of the capital structure of Portuguese firms with direct investment in Angola and to understand whether the determinants normally considered by standard finance theory are in line with those used by firms when structuring their capital structure policy to participate in the specific market of Angola.

Setting: This article examines 26 large Portuguese firms with investments in Angola using econometric panel data for the period 2006-2010.

Methods: The study applied fixed and random effects methods and panel-corrected standard errors that maintain efficiency and unbiased behaviour even in the presence of panel-level heteroscedasticity and contemporaneous correlation of observations among panels.

Results: The results provide evidence that the determinants normally considered by standard finance theory are in fact - in terms of sign and coefficient dimension - those used by firms for structuring their capital structure policy when involved in the internationalisation process of entering Angola. Specifically, age, asset structure, return on assets and tangibility have a positive influence on the capital structure of Portuguese firms that have invested in Angola, while non-debt tax shields and liquidity have a negative influence on these companies' leverage ratios. When comparing our results with studies that have analysed the capital structure determinants of listed Portuguese firms - firms belonging to the PSI 20 Index and large firms in the Portuguese corporate sector - we found similarities in the sign and coefficient dimension of the determinants of capital structure. However, the profitability coefficient sign is in line with the trade-off framework (i.e. profitability is positively related to debt) but not with pecking order theory (i.e. profitability is negatively related to debt).

Conclusion: Our results suggest that the high-growth Angolan market is seen by larger Portuguese firms as a low-risk diversification process because of the economic hardship Portugal has gone through, as well as cultural and linguistic similarities to Portugal. As such, the Angolan market is seen as an extension of the Portuguese domestic market that has increased potential. This scenario potentially reduces the firm default probability and the cost of debt. Maintaining the tax shield benefits of debt and decreasing the cost of debt - through a reduction in the default probability - have induced profitable firms to use more debt.

\section{Introduction}

Capital structure has always been a polemical subject when it comes to financial theory. The selection of which capital structure to follow in a given project is a crucial decision, given the need to maximise returns for all firms' stakeholders (Abor \& Biekpe 2009) and the way this choice can interfere with firms' capacity to deal with an external competitive environment (Abor 2005).

Since the groundwork research done by Modigliani and Miller (1958), several studies have attempted to determine the optimal capital structure, particularly research concerned with bankruptcy cost, agency theory and pecking order theory. These theories suggest that the selection of an appropriate capital structure depends on the features that determine the various costs and benefits associated with debt and/or equity financing. Therefore, the study of the determinants that influence capital structure is clearly of vital importance.

Although much research has been done on market imperfections, bankruptcy costs and information asymmetry, there are few studies on firms' capital structure in Africa (Abor 2005; Abor \& Biekpe 2009; Boateng 2004; Ezeoha \& Okafor 2010). Moreover, documented studies have 
not been conducted on the determinants of the capital structure of firms belonging to less intensely developed countries with investments on the African continent. Accordingly, the main purpose of this article is to identify the key determinants of the capital structure of Portuguese firms with investments in Angola.

Angola had a civil war from 1975 to 2002 . The end of the civil war provided a wide range of investment opportunities, mainly because of the shortage of numerous goods and services, as well as the presence of a significant domestic market with a high purchasing power in some social strata. This opportunity combined with the small psychic distance between Portugal and Angola to open a window of opportunity for many Portuguese firms to invest in Angola, where they innovated and sometimes created completely new concepts for this market but, sometimes, took on high risks. By studying the decisions made about the capital structure of Portuguese firms with investments in Angola, one can explore how these investors decide what the best capital structure policy for their investments is, providing this field of study with a new perspective.

This article analyses Portuguese firms that have direct investments in Angola, in the form of either branches or subsidiaries but with headquarters in Portugal, with the goal of identifying the determinants of their capital structure. The objective is to understand whether the determinants normally considered by standard finance theory are, in fact, those used by firms for structuring their capital structure policy when participating in the specific market of Angola.

The article is organised as follows: After this brief introduction, a review of the literature on capital structure is described in the section 'Capital structure: Literature review'. In the section 'Determinants of capital structure and research hypotheses', the determinants of capital structure are examined. In the section 'Data, estimation methodology and model', the research methodology is presented. The results are presented in the section 'Main results and discussion'. Lastly, the discussion of findings and conclusions are presented.

\section{Capital structure: Literature review}

The capital structure theory has been quite often debated in the corporate finance literature. It concerns the ways firms use equity and debt capital to finance their assets.

Modigliani and Miller (1958) developed three crucial irrelevance propositions about capital structure theory: the value of a firm or project is independent from its financial structure, the value of the firm or project increases with debt in direct proportion to the equity/debt capital ratio and, lastly, the weighted average cost of capital remains unchanged regardless of the financing source used. Although this fundamental theory has replaced Durand's (1952) traditional theory, in which he states that capital structure influences firms' value, research contradicting this idea has been carried out to explain the way firms finance themselves. Along these lines, Modigliani and Miller (1958) draw some further conclusions: a firm's market value is independent of its capital structure, the higher the expected returns, the higher the risk involved and, lastly, the rate of return demanded by shareholders of indebted firms is higher than the rate of return demanded by shareholders of non-indebted firms.

Myers (1977) asserts that firms that are quite indebted may not perform projects in which the net present value is positive, as generated cash flows will mostly be destined to cover already assumed commitments and the surplus will not be enough to cover the initial investment. Later, Myers (1993) claimed that it is possible to estimate the optimal debt ratio of a firm by considering the net tax benefits, which are related to the existence of debt and its associated costs.

Brealey, Myers and Allen (2007) argue that capital structure acknowledges that debt ratios objectives may vary from firm to firm. Accordingly, firms with tangible assets and high earnings before income taxes may need to establish high debt ratios so that they can secure tax benefits. Corporations with low profits - with risky intangible assets - should resort to their own equity.

According to Crnigoj and Mramor (2009) and Tahir and Alifiah (2015), the current theory of capital structure is based on two strands: the trade-off and pecking order theories. Falling within the first thread, Chang and Yu (2010) state that the optimal capital policy of firms is based on the trade-off between debt tax benefits and bankruptcy costs.

According to the pecking order theory, firms do not seek an optimal capital structure. The structure instead reflects financing options taken in the past (Myers 1984; Myers \& Majluf 1984), that is, a hierarchical order is followed when choosing financing sources because of information asymmetry. This hierarchy of sources stems from the financing of investments, first, with internal funds (i.e. retained earnings), followed by new debt issuance and, lastly, by new shares issuance (Brealey et al. 2007).

This information asymmetry theory also is one of the fundamental theories that help explain capital structure. Information asymmetry occurs when managers have more information than investors (Brealey et al. 2007). The cited authors argue that information asymmetry jeopardises the choice between internal or external financing and new share issuance.

According to Istaitieh and Rodríguez-Fernández (2006), the capital structure literature can be classified according to the following typology: the stakeholder theory of capital structure, the theory of market structure and the competitive strategy theory. The first theory relies on the idea that debt affects non-financial agents such as collaborators and suppliers, as well as shareholders and creditors. Therefore, both non-financial agents (i.e. clients, workers and suppliers) 
and financial agents (i.e. shareholders and bondholders) need to be taken into account.

Regarding the second theory, the level of debt might affect the market, and the market structure also can impact the capital structure of firms (Santos, Moreira \& Vieira 2013, 2014, 2015). Ultimately, the last theory - competitive strategy theory - states that the capital structure of firms is related to their competitive strategy, as both aspects strive to leverage the firms (Istaitieh \& Rodríguez-Fernández 2006; Oinoa \& Ukaegbu 2015).

In their definition of capital structure, Silva and Queirós (2009) claim that it is important to analyse the trade-off between equity and debt as this trade-off will influence the degree of enforceability and the cost of each financing source in the capital structure. An accurate definition of short-, medium- or long-term maturities and of sources of capital (i.e. equity and/or debt) is important to minimise capital costs and the risk of not fulfilling firms' financial obligations and, at the same time, to maximise the return of invested capital (Menezes 2003).

Boateng (2004) developed a different perspective on the definition of capital structure. He argues that this structure needs to be defined based on the properties of the various costs and benefits linked to debt and equity. However, Ezeoha and Okafor (2010) and Chadha and Sharma (2015) claim that the definition of capital structure depends on the dominant character of firms' structure in each country and on the level of development of the markets involved.

In addition, Parsons and Titman (2008) and Chadha and Sharma (2015) assert that changes in capital structure are influenced not only by the availability of capital generated internally but also by market conditions. Andrikopoulos (2009) also states that managers' salaries and firms' value should be taken into account when defining their capital structure.

Titman and Wessels (1988) conclude that capital structure is chosen in a systematic way, which agrees with Modigliani and Miller's (1958) argument. However, the evidence against the hierarchy of financing theory shows that external financing is valued and that firms issue more shares than debt (Frank \& Goyal 2003). After studying the Indian market, Handoo and Sharma (2014) concluded that liquidity, size, profitability and growth might have different results when measured as short-term debt, long-term debt or total debt ratio, each having a different impact on the leverage structure of listed Indian firms.

Hovakimian, Hovakimian and Tehranian (2004), after studying financing options, concluded that the importance of return on shares is related to the search for leverage. Nevertheless, the cited authors also argue that firms with high profits do not compensate for accumulated deficits with leverage through the issuance of debt.
Rocca et al. (2009) conclude that the diversification of choices is important in debt financing. Diversified firms cannot be considered a homogeneous group, and they increase their use of debt to profit from tax deductions and benefits.

Saito and Hiramoto's (2010) study of the impacts of international activities on capital structure found that Brazilian multinationals use more debt in international activities, at $9.6 \%$ of their leverage, of which $5.8 \%$ comes from long-term sources. International activity, therefore, increases short- and long-term leverage. The cited authors also maintain that international activity is positively related with the use of external debt and that multinationals, on average, add more than $12.7 \%$ external debt to their capital structure. The effect of foreign presence on the leverage of domestic firms was subsequently analysed by Anwar and Sun (2015), who concluded that the impact of a foreign presence on leverage is important, although this varies from industry to industry because of heterogeneity of productivity patterns.

\section{Determinants of capital structure and research hypotheses Asset structure}

As leverage is negatively influenced by asset structure, firms tend to prefer short-term rather than long-term debt (Daskalakis \& Psillaki 2008). Therefore, small- and mediumsized businesses, having fewer fixed assets, usually find it more difficult to secure loans (Abor \& Biekpe 2009), while firms with greater fixed assets do not apply for loans as often (Psillaki \& Daskalakis 2009).

Brito, Corrar and Batistella (2006) and Menike (2015) argue that asset structure positively influences long-term debt, that is, firms that have fixed assets to offer as collateral for their debts are considered more creditworthy. However, Karadeniz et al. (2009) maintain that fixed assets and returns on assets have a negative influence on debt and debt ratio. Therefore, the following hypothesis was formulated for the present study:

H1: A relationship exists between capital structure and asset structure.

\begin{abstract}
Age
Age is usually expected to have a positive effect on capital structure - as represented by debt to equity ratio - given that firms increase their liquidity capacity over the years. Abor and Biekpe (2009) conclude that age is important when obtaining funds through loans as firms that have been in their business for a considerable period have collateral to offer to banks if they cannot pay their debt. Menike (2015) also found that the younger the firm, the more prone it is to resort to long-term debt.
\end{abstract}

For Bhaird and Lucey (2010), the age of a firm positively influences profit retention but negatively influences longterm financing. Ahmed, Ahmed and Ahmed (2010) assert 
that age negatively influences leverage. It is worth pointing out, in this context, that leverage variation might be explained by the increase in the age of firms, which could compel managers to focus a significant part of their attention on the intrinsic characteristics of their firm and its financing decisions (Chadha \& Sharma 2015; Kayo \& Kimura 2011). Therefore, the following hypothesis was considered in the present study:

$\mathbf{H} 2$ : A relationship exists between capital structure and age.

\section{Liquidity}

Liquidity is measured through the current assets/current liabilities ratio, providing information on whether firms can meet their short-term financial commitments. Ahmed et al. (2010) conclude that liquidity has a negative impact on the debt to equity ratio, that is, equity capital will increase more substantially over time than liabilities. Antão and Bonfim (2008) and Sbeiti (2010) assert that liquidity has a negative impact on financial leverage, which is to say that firms with higher levels of liquidity tend to avoid increasing their use of external debt, a finding that gave rise to this hypothesis in the present study:

H3: A relationship exists between capital structure and liquidity.

\section{Intangibility}

The level of intangible activity is expected to have a positive impact on leverage as firms with high expenditures on research and development need higher levels of external capital than internal capital. This result suggests that internal financing is not enough to support the high-level growth of these firms regarding their increased need for investment (Bhaird \& Lucey 2010). Thus, the following hypothesis was suggested for the present study:

H4: A relationship exists between capital structure and intangibility.

\section{Profitability}

Based on pecking order theory, Myers (1984) argues that decisions on capital structure follow a hierarchical order when it comes to choosing financing sources. This hierarchy mainly consists of financing investments with retained earnings, followed by new debt issues and, lastly, by the issuance of new equity. Consequently, firms' profitability has a negative impact on their use of debt (Chang, Lee \& Lee 2009; Nunkoo \& Boateng 2010). Rebelo (2006) also asserts that profitability has a negative impact on total debt, and Abor (2005) claims that profitability has a negative impact on short-term debt.

Some other studies (Chadha \& Sharma 2015; Chang et al. 2009; Crnigoj \& Mramor 2009; Daskalakis \& Psillaki 2008; Psillaki \& Daskalakis 2009) found that profitability positively influences leverage, based on the trade-off theory. According to Jensen and Meckling (1976), Myers (1977) and Harris and Raviv (1990), the tax shield benefits of debt outweigh any increase in debt cost, and this is related to a potential increase in the probability of default, which will induce profitable firms to use more debt. Psillaki and Daskalakis (2009) add that:

The pecking order theory is especially appropriate for small and medium-sized firms ... These firms do not typically aim at a target debt ratio ... Instead, their financing decisions follow a hierarchy, with a preference for internal over external finance, and for debt over equity. (pp. 325-326)

Abor and Biekpe (2009) link profitability with age, risk and growth. They found that profitability has a negative relationship with age and growth. At the same time, risk has a positive link with profitability. Lastly, Brito et al. (2006) found that profitability is not a crucial factor in capital structure. Thus, the following hypothesis was formulated for the present study:

H5: A relationship exists between capital structure and profitability.

\section{Tangibility}

Firms with higher tangible assets can use debt more easily as creditors believe these firms can fulfil their obligations more easily. Therefore, tangibility should positively influence leverage.

While Couto and Ferreira (2010) and Chadha and Sharma (2015) assert that tangibility is a determinant factor of capital structure, Nunkoo and Boateng (2010) argue that tangibility has a positive influence on leverage. ${ }^{1}$ In addition, Onaolapo and Kajola (2010) contend that tangibility is negatively influenced by profitability, and Serrasqueiro and Nunes (2010) maintain that there is no positive relationship between debt and tangibility. However, Ahmed et al. (2010) suggest that leverage has no statistical relevance in terms of asset tangibility. Accordingly, the following hypothesis was suggested in the present study:

H6: Arelationship exists between capital structure and tangibility.

\section{Non-debt tax shields}

Non-debt tax shields (NDTS) are characterised by the weight assigned to the depreciation of assets (Rebelo 2006). Although, for Chadha and Sharma (2015), NDTS influence the capital structure of Indian manufacturing firms, according to Rebelo (2006), NDTS do not seem to be a factor when it comes to technology firms' level of debt. However, Serrasqueiro and Nunes (2010) say that there is no relationship between NDTS and debt. Therefore, it was decided to test the following hypothesis in the present study:

H7: A relationship exists between capital structure and NDTS.

\section{Growth}

The growth of firms is expected to have a positive impact on leverage. However, some studies have concluded otherwise, which might be a consequence of using different variables for growth, such as net assets growth rate (Couto \& Ferreira 1.For more discussion see among others Serrasqueiro and Rogão (2009), Antão and Bonfim (2008) and Kyereboah-Coleman (2007). 
2010; Rebelo 2006), total assets growth rate (Chang et al. 2009; Nunkoo \& Boateng 2010) or speed of adjustment (Oinoa \& Ukaegbu 2015). Sbeiti (2010) argues that growth needs to be defined through the following ratio: total assets book value minus net assets book value and the market value of equity over the total assets book value.

Another definition given for growth is firms' market value divided by the firms' book value (Karadeniz et al. 2009). Although Abor and Biekpe (2009) define growth as sales growth, Brito et al. (2006) use a sales logarithm (Ln).

Studies have produced contradictory results. While Couto and Ferreira (2010) assert that growth does not explain the level of debt, Rebelo (2006) and Chadha and Sharma (2015) argue that growth has a positive impact on the total debt. Moreover, Chang et al. (2009), Nunko and Boateng (2010) and Sbeiti (2010) found that growth has a negative impact on leverage, when growth is measured by the market-to-book ratio (Chang et al. 2009) and by market leverage (Sbeiti 2010).

Karadeniz et al. (2009) maintain that growth and debt are not correlated in Turkish firms. However, Brito et al. (2006) assert that growth has a positive relationship with long-term debt. This evidence goes against bankruptcy cost and agency cost theories but confirms the information asymmetry theory, that is, firms finance their growth through debt to indicate to the market that their shares are underestimated (Brito et al. 2006).

Lastly, Abor and Biekpe (2009) also argue that growth has a positive relationship with long-term debt as growth usually puts pressure on retained earnings. For example, highgrowth Ghanaian firms incur more external debt when they finance operations. Nevertheless, as financing opportunities can create conflicts between creditors and managers, small firms use more short-term debt (Abor \& Biekpe 2009).

\section{Size}

As large firms are usually more diversified than smaller firms are, they are less prone to financial difficulties and have fewer bankruptcy costs (Brito et al. 2006; Omet et al. 2015). Therefore, it is expected for size to have a positive influence on leverage. ${ }^{2}$

Although Nunkoo and Boateng (2010) maintain that size has a negative influence on leverage, most studies argue otherwise (Ahmed et al. 2010; Brito et al. 2006; Crnigoj \& Mramor 2009; Daskalakis \& Psillaki 2008; Menike 2015; Psillaki \& Daskalakis 2009; Sbeiti 2010).

Bhaird and Lucey (2010) were able to determine that size has a positive relationship with profit since surviving firms are increasingly dependent on internal capital and their accumulated profits are reinvested. Lastly, Karadeniz et al. (2009) found that size does not appear to be linked to debt ratio.

2.For more discussion see, among others, Couto and Ferreira (2010), Serrasqueiro and Rogão (2009), Antão and Bonfim (2008) and Kyereboah-Coleman (2007).

\section{Data, estimation methodology and model \\ Data}

Studies of capital structure and the main factors considered when choosing it are increasingly important in the corporate finance literature. In this study, the goal was to analyse a specific case not studied before: Portuguese firms with direct investments in Angola. Thus, this study had the objective of verifying how the following factors influence the capital structure of Portuguese firms with subsidiaries or branches in Angola: asset structure, age, liquidity, intangibility, profitability, tangibility and NDTS. Although other determinants influence capital structure (i.e. growth and size), they were not included in this study because of the unavailability of data for the firms in our sample. Table 1 below summarises the hypotheses tested and the corresponding random variables linked with their measurement.

The sample in study comprises 26 firms dating to the period 2006-2010, which were chosen according to the availability of data. The data were gathered by using a list of the Portuguese firms with direct investments abroad, provided by the Agency for Investment and External Trade of Portugal in Luanda.

Based on this list, an analysis of the firms' websites was conducted with the objective of collecting the information available. Firms without any website or information were first contacted via e-mail to acquire the required data. In the cases in which no information was acquired, telephone calls were made. The banks on the list were not considered, given that they have a different tax code, accounting rules and operation modes. Information, thus, was collected from the following firms: Compta, Auto Sueco, FDO, Conduril, Enoport, Eurico Ferreira, Galp, Visabeira, Martifer, Mota-Engil, Monteadriano,

TABLE 1: Explained variables, explanatory variables and hypotheses.

\begin{tabular}{|c|c|c|}
\hline Variables & Hypotheses & Variables description \\
\hline \multicolumn{3}{|l|}{ Explained } \\
\hline Leverage ratio & - & $\begin{array}{l}\text { Leverage_Ratio }=\operatorname{Ln}(\text { total } \\
\text { liabilities/total assets) }\end{array}$ \\
\hline \multicolumn{3}{|l|}{ Explanatory } \\
\hline Asset structure & $\begin{array}{l}\text { H1: A relationship exists } \\
\text { between capital structure and } \\
\text { asset structure }\end{array}$ & $\begin{array}{l}\text { Asset_Structure }=\operatorname{Ln}(\text { fixed } \\
\text { assets/total assets) }\end{array}$ \\
\hline Age & $\begin{array}{l}\mathrm{H} 2 \text { : A relationship exists } \\
\text { between capital structure and } \\
\text { age }\end{array}$ & Age $=\operatorname{Ln}($ Age $)$ \\
\hline Liquidity & $\begin{array}{l}\text { H3: A relationship exists } \\
\text { between capital structure and } \\
\text { liquidity }\end{array}$ & $\begin{array}{l}\text { Liquidity }=\text { Ln(total net assets/ } \\
\text { short-term debt) }\end{array}$ \\
\hline Intangibility & $\begin{array}{l}\text { H4: A relationship exists } \\
\text { between capital structure and } \\
\text { intangibility }\end{array}$ & $\begin{array}{l}\text { Intangibility }=\operatorname{Ln}(\text { intangible } \\
\text { assets) }\end{array}$ \\
\hline Profitability & $\begin{array}{l}\text { H5: A relationship exists } \\
\text { between capital structure and } \\
\text { profitability }\end{array}$ & $\begin{array}{l}\text { Return_on_sales = Ln(net } \\
\text { income/sales); Return_on_- } \\
\text { Assets = Ln(earnings before } \\
\text { interests/total assets) }\end{array}$ \\
\hline Tangibility & $\begin{array}{l}\text { H6: A relationship exists } \\
\text { between capital structure and } \\
\text { tangibility }\end{array}$ & $\begin{array}{l}\text { Tangi }=\operatorname{Ln}(\text { tangible fixed assets } / \\
\text { total assets) }\end{array}$ \\
\hline $\begin{array}{l}\text { Non-debt tax } \\
\text { shields }\end{array}$ & $\begin{array}{l}\text { H7: A relationship exists } \\
\text { between capital structure and } \\
\text { NDTS }\end{array}$ & $\begin{array}{l}\text { Non-Debt_Tax_Shields }= \\
\text { Ln(depreciation/total net assets) }\end{array}$ \\
\hline
\end{tabular}


Orey, Petrotec, PT, Sumol, Tomás de Oliveira, Obrecol, EFACEC, Glintt, Opway, M. Couto Alves, Abrantina, Soares da Costa, Somague, Teixeira Duarte and MSF.

The data were extracted from the consolidated financial reports and statements of these 26 firms, which were normally made available on their websites. The collected data cover the following variables: total assets, fixed assets, tangible fixed assets, intangible assets, total net assets, depreciations, equity capital, short-term debt, long-term debt, total debt, liabilities, net profits, distributed dividends, sales, earnings before taxes, price per share, size and age.

\section{Estimation methods and model}

According to Hsiao (2003), panel data methodology uses a set of data that follows a given sample over a period, providing multiple observations for each variable in the sample. This methodology increases the amount of data because of the cross between longitudinal and time series study methods. This increases the degrees of freedom and decreases the collinearity between explanatory variables, which leads to a greater efficiency of the econometric estimation. This methodology also allows the researcher to analyse various economic issues that cannot be accurately studied using only longitudinal or time series studies. The main advantages of this methodology are (Wooldridge 2010) that the estimates are more efficient as the variables are less collinear, the opportunity to analyse individual dynamics, more information about the ordering of events over time and the opportunity to control any heterogeneity not identified individually.

Fixed and random effects models were considered (two estimation methods inside the panel data models) when specifying the econometric model. The rationale behind the choice between the two models are: the fixed effects model is the most suited to analyse the exclusive impact of variables that change over time - that is, this model is suitable for studying the causes of change inside an entity (Gujarati 2003; Hsiao 2003); in random effects model, changes in individuals or cases are seen to be random and not correlated with the independent variables included in the conceptual model, allowing the variables that do not change over time to play an important role as explanatory variables, in marked contrast to the fixed effects model (Johnston \& Dinardo 1997).

Complementarily, a test created by Hausman allows researchers to ascertain which model is more suitable: the null hypothesis assumes that the random effects estimator is the most appropriate (Johnston \& Dinardo 1997). Thus, if the null hypothesis is rejected, the random effects model cannot be the most appropriate, and the fixed effects model should be chosen (Gujarati 2003).

Although, panel data models can be estimated even when there are severe deviations from the classical assumptions and 'complex error compositions' are present (Basu \& Rajeev 2013; Couto \& Ferreira 2010; Marques \& Fuinhas 2012:11; Petersen 2009), the inadequate verification of the existence of heteroscedasticity and autocorrelation phenomena in panel data models can lead to inefficiency and biased estimates of coefficients and standard errors.

Therefore, the panel data model needs to be complemented by carrying out tests to verify the presence or absence of heteroscedasticity and cross-sectional independence. Furthermore, whenever there are divergences regarding the classical assumptions of the aforementioned cases, it is necessary to introduce the respective corrections, not to compromise the suitability of the results.

The procedure needs to be as follows. After testing for the presence of heteroscedasticity and panel autocorrelation, if any deviation from the classical assumptions is detected, Beck and Katz's (1995) correction factor - panel-corrected standard errors $(\mathrm{PCSE})^{3}$ - should be applied. The PCSE estimator performs well in the presence of panel-level heteroscedasticity and contemporaneous correlation of observations among panels. ${ }^{4}$

Marques and Fuinhas (2012), who studied the robustness of results obtained by the PCSE estimator as compared with the results obtained by standard panel data estimators (i.e. fixed and random effects), assert that the use of the PCSE model is indeed the most adequate method, as this provides the best results. To test the formulated hypotheses empirically and take into account the defined methodology, the following model was defined $^{5}$ :

$$
\begin{aligned}
\text { Leverage_Ratio }_{i t} & \\
= & \beta_{1}+\beta_{2} \text { Asset_Structure }_{i t}+\beta_{3} \text { Age }_{i t}+\beta_{4} \text { Liquidity }_{i t} \\
+ & \beta_{5} \text { Intangible_Activity_Level }_{i t}+\beta_{6} \text { Return_on_Sales }_{i t} \\
+ & \beta_{7} \text { Return_on_assets }_{i t}+\beta_{8} \text { Tangi }_{i t}+\beta_{9} \text { Non-Debt }_{-} \\
& \text {Tax_Shields } \\
& +d_{1 i}+d_{1 t}+\mu_{i t}
\end{aligned}
$$

\section{Results and discussion}

To carry out the data analysis in this study, static panel data and econometric methodologies using the program STATA 11 were chosen. This study's data produced an unbalanced panel, given the lack of information for all variables in all the years covered. Table A1 in Appendix A shows the descriptive statistics. ${ }^{6}$

3 Which is the most efficient when the data do not have serial correlation (autocorrelation), comparing its results with those achieved from the classical panel (autocorrelation), comparing its results with
data estimators (Fixed and Random Effects).

4.Additionally, it allows: the error term to be correlated over the firms, the use of firstorder autoregressive process for error term over time and the error term to be heteroscedastic (Cameron \& Triverdi, 2009; Marques \& Fuinhas 2012).

5.In this model, $\beta$ values represent the coefficients of the independent variables. represents the entity (firm) and $t$ represents the temporal unit (year). $\mu_{\mathrm{it}}$ represents the error term.

6. From observation of the descriptive statistics, it is possible to conclude that the debt of Portuguese firms with direct investment in Angola is on average around $110 \%$. of Portuguese firms with direct investment in Ango woreover, the liquidity, return on sales, return on assets and NDTS are variables with some The dir values. The Portuguese firms with direct investment in Angola appear to be moderately volatile in asset structure, intangibility and tangibility, which suggests some degree of stability. 
Following established procedure, an initial analysis of the data was made. The results of the specification tests are outlined in Table 2.

A Wooldridge test was carried out to test the presence of autocorrelation. The results support the following conclusion: at a significance level of 5\%, the null hypothesis of no first order serial correlation cannot be rejected, that is, there is no serial correlation.

Following Baum's (2001) guidelines, a modified Wald test was run to test for groupwise heteroscedasticity in the residuals of a fixed effect regression model. As seen in Table 2, the null hypothesis of homoscedasticity is rejected, so the claim can be made that the errors exhibit groupwise heteroscedasticity. Lastly, the results of a Hausman test - the null hypothesis posits that the individual-level effects are adequately modelled by a random effects model - support the following conclusion: the null hypothesis is rejected, and the fixed effects model is the most suitable model for this study.

Given that there is a deviation in classical assumptions, in particular when it comes to the existence of heteroscedasticity, the PCSE estimator had to be used to rectify the deviation.

Table 3 displays the results of the model using fixed effects and random effects and applying the PCSE estimators. For the first two models, the results are presented without any model correction [i.e. conventional standard errors (CSE)], using robust standard error (RSE).

TABLE 2: Specification tests

\begin{tabular}{lcc}
\hline Type of test & Random effects & Fixed effects \\
\hline Modified Wald test $(X 2)$ & - & $234.59^{*}$ \\
Wooldridge test $\mathrm{F}(\mathrm{N}(0,1))$ & 4.501 & 4.501 \\
Hausman test & $20.26^{*}$ & - \\
\hline
\end{tabular}

*, shows a significance level of $1 \%$.
The results of the fixed effect and random effect models, with CSE and RSE, allow a comparison of the robustness of results achieved by the PCSE estimator with the results achieved by fixed and variable effects estimators. The analysis was then continued using data from the PCSE estimator as it is considered to be more robust and to provide better results.

From all the hypotheses subjected to empirical analysis, only two were not statistically significant: Hypotheses 4 and, partially, 5. These postulated the existence of a relationship between capital structure and the level of intangibility and return on sales and/or return on assets. For the second hypothesis, only the relationship with return on sales was not statistically significant.

The analysis results shown in Table 3 confirm that variables such as asset structure, age, liquidity, tangibility and NDTS have a $p$-value below $5 \%$. The return on assets has a $p$-value below $10 \%$. This leads to the rejection of the null hypothesis of the aforementioned variables not being statistically significant.

As can be observed, the asset structure (i.e. Hypothesis 1) has a positive impact on the leverage ratio (0.2079). This conclusion goes against what Rebelo (2006) proposes but corroborates the findings of Brito et al. (2006), who claim that the asset structure has a positive influence on long-term debt, which overlaps with its negative impact on short-term debt (Chadha \& Sharma 2015; Handoo \& Sharma 2014; Omet et al. 2015).

A firm's age (i.e. Hypothesis 2) also has a positive impact on the leverage ratio (0.1483). This conclusion agrees with the results achieved by Abor and Biekpe (2009) and Chadha and Sharma (2015). They assert that age is an important factor when accessing capital through loans. The case of Portuguese

TABLE 3: Models with application of the robust standard error to random and fixed effects models

\begin{tabular}{|c|c|c|c|c|c|c|c|c|c|c|c|c|}
\hline \multirow[t]{3}{*}{ Variables } & \multicolumn{4}{|c|}{ PCSE } & \multicolumn{4}{|c|}{ RSE } & \multicolumn{4}{|c|}{ CSE } \\
\hline & \multicolumn{2}{|c|}{ Hetonly } & \multicolumn{2}{|c|}{ Corr(AR1) hetonly } & \multicolumn{2}{|c|}{ Fixed effects } & \multicolumn{2}{|c|}{ Random effects } & \multicolumn{2}{|c|}{ Fixed effects } & \multicolumn{2}{|c|}{ Random effects } \\
\hline & Coefficient & $p$ & Coefficient & $p$ & Coefficient & $p$ & Coefficient & $p$ & Coefficient & $p$ & Coefficient & $p$ \\
\hline $\begin{array}{l}\text { Asset__ } \\
\text { Structure }\end{array}$ & 0.2079 & $0.009 * * *$ & 0.2011 & $0.016^{* *}$ & 0.1703 & 0.316 & 0.2174 & $0.098^{*}$ & 0.1703 & $0.050^{*}$ & 0.2174 & $0.003 * * *$ \\
\hline Age & 0.1483 & $0.000 * * *$ & 0.1390 & $0.017 * *$ & 0.2784 & 0.267 & 0.1473 & $0.052 *$ & 0.2784 & 0.400 & 0.1473 & $0.046 * *$ \\
\hline Liquidity & -0.4566 & $0.000 * * *$ & -0.5174 & $0.000 * * *$ & -0.6412 & $0.000 * * *$ & -0.5255 & $0.007 * * *$ & -0.6411 & $0.000 * * *$ & -0.5255 & $0.000 * * *$ \\
\hline Intangibility & 0.0148 & 0.289 & 0.0149 & 0.341 & -0.0205 & 0.271 & 0.0128 & 0.508 & -0.0205 & 0.542 & 0.0128 & 0.479 \\
\hline $\begin{array}{l}\text { Return_on_ } \\
\text { sales }\end{array}$ & 0.0248 & 0.378 & 0.0291 & 0.318 & 0.0382 & 0.353 & 0.0322 & 0.238 & 0.0382 & 0.315 & 0.0322 & 0.210 \\
\hline $\begin{array}{l}\text { Return_on_ } \\
\text { assets }\end{array}$ & 0.1178 & $0.073^{*}$ & 0.1517 & $0.046 * *$ & 0.4089 & $0.008 * * *$ & 0.1780 & 0.175 & 0.4089 & $0.000 * * *$ & 0.1780 & $0.002 * * *$ \\
\hline Tangi & 0.1675 & $0.029 * *$ & 0.1997 & $0.031 * *$ & -0.1126 & 0.498 & 0.2158 & $0.091 *$ & -0.1126 & 0.623 & 0.2158 & $0.028 * *$ \\
\hline $\begin{array}{l}\text { Non-Debt } \\
\text { Tax_Shields }\end{array}$ & -0.1999 & $0.015 * *$ & -0.2664 & $0.003 * * *$ & -0.2093 & 0.271 & -0.2586 & $0.083^{*}$ & -0.2093 & $0.021 * *$ & -0.2586 & $0.000 * * *$ \\
\hline Constant & -1.1304 & $0.002 * * *$ & -1.2423 & $0.006 * * *$ & -1.6314 & $0.081^{*}$ & -1.1820 & $0.002 * * *$ & -1.6314 & 0.223 & -1.1820 & $0.023 * *$ \\
\hline Observations & 70 & - & 70 & - & 70 & - & 70 & - & 70 & - & 70 & - \\
\hline F test & - & - & - & - & 12.29 & $0.000 * * *$ & - & - & 15.72 & $0.000 * * *$ & 98.11 & $0.000 * * *$ \\
\hline Wald $(\chi 2)$ & 82.69 & $0.000 * * *$ & 57.82 & $0.000 * * *$ & - & - & 37.49 & $0.000 * * *$ & 0.1703 & $0.050 *$ & 0.2174 & $0.003 * * *$ \\
\hline
\end{tabular}

PCSE, panel-corrected standard errors; RSE, robust standard errors; CSE, conventional standard errors.

Dependent variable: Liabilities/Total Assets; Corr(AR1) - first order autocorrelation AR(1), in which the coefficient of AR(1) is the same for all panels; hetonly specifies that deviations are taken as heteroscedastic. The item of test $F$ tests the null hypothesis of there not being significance for the model on the whole (of the estimated parameters). The Wald test ( $\mathrm{X}$ ) evaluates the null hypothesis of there not being significant for all coefficients of all explanatory variables.

$* * *, * *, *$, refer to significance level from $1 \%, 5 \%$ to $10 \%$, respectively. 
firms with investments in Angola shows that the age of firms can be used as an advantage to obtain financing for their investments in Angola.

Liquidity (i.e. Hypothesis 3) has a negative impact on the leverage ratio $(-0.4566)$, which is in agreement with the results obtained by Sbeiti (2010), who maintains that firms with a higher level of liquidity usually avoid the use of external debt. Concerning the firms studied, the liquidity level is in most cases used to finance their own assets in Angola.

Profitability was divided into return on sales and return on assets (i.e. Hypothesis 5). However, only the positive (0.1178) relationship between the leverage ratio and returns on assets is statistically significant, which is in agreement with Psillaki and Daskalakis (2009), Crnigoj and Mramor (2009) and Chang et al.'s (2009) conclusions. Therefore, we can say that it is clear that the firms analysed choose to invest in Angola when their return on assets allows it, an approach that tries to diminish investment risks and pursue a path of sustained growth. The fact that return on sales is not statistically significant is related to the fact that, when firms decide to invest in Angola, they consider not only normal, short-term business outcomes but also the outcomes of normal, longterm investment.

The assets' tangibility (i.e. Hypothesis 6) has a positive influence on the leverage ratio (0.1675) since firms with higher tangible assets can more easily use debt because they have collateral to present to banks. This conclusion was also reached by Nunkoo and Boateng (2010), Handoo and Sharma (2014), Chadha and Sharma (2015) and Omet et al. (2015).

NDTS (i.e. Hypothesis 7) maintain a negative relationship with the leverage ratio (-0.1999). This conclusion contradicts the findings of authors such as Rebelo (2006) and Serrasqueiro and Nunes (2010), who did not find any evidence that this factor has an influence on debt. The present study shows that the investment of Portuguese firms in Angola has an increasingly higher importance in depreciations of assets, as a consequence of the investments made.

\section{Conclusion}

In this study, the factors that influence the choice of the capital structure of 26 Portuguese firms with investments in Angola were examined. With the exception of these firms' profitability, we found similarities in the sign and coefficient dimension of capital structure determinants when we compared our results with studies that analysed the capital structure determinants of listed Portuguese firms, firms belonging to the PSI 20 Index and large firms in the Portuguese corporate sector (Antão \& Bonfim 2008; Couto \& Ferreira 2010; Serrasqueiro \& Rogão 2009). These comparisons allowed us to conclude that making direct investments in a foreign market - specifically an African market such as Angola - during the process of internationalisation of firms' investment does not change financing policy, in particular, the sign and coefficient dimension of capital structure determinants. The studies that were used in our comparison of results used samples of large Portuguese, non-financial firms with their investments focused on the Portuguese and European markets (i.e. their main markets). Moreover, the firm size of our sample matches the firm size of other samples of large Portuguese, non-financial firms, with the only difference being their international investments.

Regarding the results, as expected, asset structure is positively related with the leverage ratio, with a coefficient of 0.2079. Likewise, tangibility is also positively related with the leverage ratio. When the sign and coefficient dimension of the relation between tangibility and leverage in our study is compared to the above-mentioned studies, we can conclude that our result of 0.1675 is similar to the other studies' results. Serrasqueiro and Rogão (2009) got 0.13159; Antão and Bonfim (2008), 0.07; and Couto and Ferreira (2010), 1.2405 - in this case, only regarding the coefficient sign. This result is in tune with more recent studies outside Portugal (Chadha \& Sharma 2015; Handoo \& Sharma 2014; Omet et al. 2015).

A firm's age and profitability - represented by the return on assets - are also positively related with the leverage ratio. In the specific case of the relationship between profitability and leverage, compared with other studies in terms of sign and coefficient dimension, our result of 0.1178 has the same dimension but with an inverse sign in contrast to what was obtained by Serrasqueiro and Rogão (2009), -0.17137; and Couto and Ferreira (2010), -0.1330 . This result is also similar to that of more recent studies outside Portugal (Chadha \& Sharma 2015; Handoo \& Sharma 2014; Omet et al. 2015).

Lastly, liquidity and NDTS are negatively related with the leverage ratio. The liquidity coefficient is -0.4566 , as compared with Antão and Bonfim's (2008) -0.01. The NDTS coefficient is -0.1999 , as compared with Antão and Bonfim's (2008) -0.04 and Couto and Ferreira's (2010) -0.0003.

In general, this leads to the conclusion that the capital structure determinants normally considered by standard finance theory are, in fact - in terms of sign and coefficient dimension - similar to those used by Portuguese firms investing in the Angolan market. However, the sign of the profitability coefficient is in line with the trade-off framework (i.e. profitability is positively related to debt) and not with pecking order theory (i.e. profitability is negatively related to debt). The explanation offered for this finding is that internationalisation to Angola is seen by Portuguese firms as a diversification strategy involving a market in which the cultural and language differences are quite low. As such, taking into account the high-growth rate of the Angolan market vis-à-vis the Portuguese market in the period studied, this investment was seen by creditors as a low-risk, highpotential one. Angola is considered, on the one hand, an extension of the Portuguese domestic market and, on the 
other hand, a way out of the crisis in the Portuguese economy. This scenario potentially reduces the firms' default probability and, as a consequence, the cost of debt. As it maintains the tax shield benefits of debt and decreases the cost of debt (i.e. through a reduction in default probability), this opportunity has induced profitable firms to use more debt.

It is possible to advance that the determinants of the capital structure of firms from less intensely developed countries investing abroad on the African continent do not necessarily differ from other previous studies (Abor 2005; Abor \& Biekpe 2009; Antão \& Bonfim 2008; Boateng 2004; Couto \& Ferreira 2010; Serrasqueiro \& Rogão 2009), which has important consequences for firms seeking a foothold in Africa. However, generalisations need to be taken cautiously, as the Portuguese firms analysed in this sample covered a period of economic hardship in Portugal, while the Angolan economy was booming.

This research also has important implications as it complements studies especially in less-endowed countries or in Africa. For example, results obtained in the hospitality industry in Turkey (Karadeniz et al. 2009) show that countries with lack of funds supply, because of underdeveloped capital marks, as is the case of African countries, might be good opportunities for firms investing abroad if these are able to lower the risks. Moreover, when analysing the Ghanaian case, one can claim that the African market is an important opportunity for internationalisation as debt is the main financing option of Ghanaian firms (Abor 2005; Abor \& Biekpe 2009) and joint ventures are natural market entry options to reduce business risk and leverage market potential (Boateng 2004).

It is important also to emphasise that foreign firms investing in Africa need to seriously take into account corporate governance decisions as government policies may not only discriminate between indigenous and foreign shareholders (Boateng 2004; Ezeoha \& Okafor 2010) but also change the rules of the game that may jeopardise foreign investment and local development alike (Boateng 2004).

This study has some limitations that conditioned the research. The first limitation is the small dimension of the sample, which consisted of 26 firms. Another limitation is the size of the firms studied. As they are all large firms, it was not possible to test whether size influences capital structure. This limitation is linked to the ease of obtaining data from large firms, as opposed to smaller firms. Lastly, not all firms had data for every year considered in this study. Although this lack of data is situational, it led to an unbalanced panel.

Considering the results of this study, it would be interesting to study in the future the same factors in firms of different sizes, such as small- and medium-sized businesses versus large firms. The purpose of this future study would be to discover the strategic differences between both types of firms.

\section{Acknowledgements Competing interests}

The authors declare that they have no financial or personal relationships that may have inappropriately influenced them in writing this article.

\section{Author's contributions}

The article is a joint work of the two authors in all of its phases.

\section{References}

Abor, J., 2005, 'The effect of capital structure on profitability: An empirical analysis of listed firms in Ghana', The Journal of Risk Finance 6(5), 438-445. https://doi. org/10.1108/15265940510633505

Abor, J. \& Biekpe, N., 2009, 'How do we explain the capital structure of SMEs in subSaharan Africa?: Evidence from Ghana', Journal of Economic Studies 36(1), 83-87. https://doi.org/10.1108/01443580910923812

Ahmed, N., Ahmed, Z. \& Ahmed, I., 2010, 'Determinants of capital structure: A case of life insurance sector of Pakistan', European Journal of Economics, Finance and Administrative Sciences 24, 7-12.

Andrikopoulos, A., 2009, 'Irreversible investment, managerial discretion and optimal capital structure', Journal of Banking \& Finance 33(4), 709-718. https://doi. org/10.1016/j.jbankfin.2008.11.002

Antão, P. \& Bonfim, D., 2008, Capital structure decisions in the Portuguese corporate sector. Financial Stability Report, Banco de Portugal, Lisbon.

Anwar, S. \& Sun, S., 2015, 'Can the presence of foreign investment affect the capital structure of domestic firms?', Journal of Corporate Finance 30, 32-43. https://doi. org/10.1016/j.jcorpfin.2014.11.003

Basu, K. \& Rajeev, M., 2013, Determinants of capital structure of Indian corporate sector: Evidence of regulatory impact, Working Paper 306, Institute for Social and Economic Change, Bangalore.

Baum, C.F., 2001, 'Residual diagnostics for cross-section time series regression models', Stata Journal 1, 101-104.

Beck, N. \& Katz, J., 1995, 'What to do (and not to do) with time-series cross-section data in comparative politics', American Political Science Review 89, 634-647. https://doi.org/10.2307/2082979

Bhaird, C.M. \& Lucey, B., 2010, 'Determinants of capital structure in Irish SMEs', Smal Business Economics 35, 357-375. https://doi.org/10.1007/s11187-008-9162-6

Boateng, A., 2004, 'Determinants of capital structure: Evidence from international joint ventures in Ghana', International Journal of Social Economics 31(3), 56-66. https://doi.org/10.1108/03068290410515411

Brealey, R.A., Myers, S.C. \& Allen, F., 2007, Princípios de Finanças Empresariais, McGraw-Hill, Madrid.

Brito, G.A., Corrar, L.J. \& Batistella, F.D., 2006, 'Fatores determinantes da estrutura de capital das maiores empresas que atuam no Brasil', Revista Contabilidade \& Finanças 18, 9-19.

Cameron, A.C. \& Trivedi, P.K., 2009, Microeconometrics using Stata, Stata Press, College Station, TX.

Chadha, S. \& Sharma, A.K., 2015, 'Determinants of capital structure: An empirical evaluation from India', Journal of Advances in Management Research 12(1), 3-14. https://doi.org/10.1108/JAMR-08-2014-0051

Chang, C., Lee, A.C. \& Lee, C.F., 2009, 'Determinants of capital structure choice: A structural equation modeling approach', The Quarterly Review of Economics and Finance 49(2), 197-213. https://doi.org/10.1016/j.qref.2008.03.004

Chang, C. \& Yu, X., 2010, 'Informational efficiency and liquidity premium as the determinants of capital structure', Journal of Financial and Quantitative Analysis 45(2), 401-440. https://doi.org/10.1017/S0022109010000098

Couto, G. \& Ferreira, S., 2010, 'Os determinantes da estrutura de capital de empresas do PSI 20', Revista Portuguesa e Brasileira de Gestão 9, 26-38.

Crnigoj, M. \& Mramor, D., 2009, 'Determinants of capital structure in emerging European economies: Evidence from Slovenian firms', Emerging Markets Finance \& Trade 45(1), 72-89. https://doi.org/10.2753/REE1540-496X450105

Daskalakis, N. \& Psillaki, M, 2008, 'Do country or firm factors explain capital structure? Evidence from SMEs in France and Greece', Applied Financial Economics 18(2), 87-97. https://doi.org/10.1080/09603100601018864

Durand, D., 1952, 'Cost of debt and equity funds for business: Trends and problems of measurement', in Universities-National Bureau (ed.), The Conference on Research in Business Finance, pp. 215-262, NBER, New York.

Ezeoha, A.E. \& Okafor, F.O., 2010, 'Local corporate ownership and capital structure decisions in Nigeria: A developing country perspective', Corporate Governance 10(3), 249-260. https://doi.org/10.1108/14720701011051893

Frank, M. \& Goyal, V., 2003, 'Testing the pecking order theory of capital structure', Journal of Financial Economics 67(2), 217-248. https://doi.org/10.1016/S0304$405 \times(02) 00252-0$ 
Gujarati, D., 2003, Basic econometrics, McGraw-Hill, New York.

Handoo, A. \& Sharma, K., 2014, 'A study on determinants of capital structure in India', IIMB Management Review 26, 170-182. https://doi.org/10.1016/j.iimb.2014. 07.009

Harris, M. \& Raviv, A., 1990, 'Capital structure and the informational role of debt', The Journal of Finance 45(2), 321-349. https://doi.org/10.1111/j.1540-6261.1990. tb03693.x

Hovakimian, A., Hovakimian, G. \& Tehranian, H., 2004, 'Determinants of target capital structure: The case of dual debt and equity issues', Journal of Financial Economics 71, 517-540. https://doi.org/10.1016/S0304-405X(03)00181-8

Hsiao, C., 2003, Analysis of panel data, Cambridge University Press, New York.

Istaitieh, A. \& Rodríguez-Fernández, J.M., 2006, 'Factor-product markets and firm's capital structure: A literature review', Review of Financial Economics 15, 49-75. capital structure: A literature review', Revien
https://doi.org/10.1016/j.rfe.2005.02.001

Jensen, M. \& Meckling, W., 1976, 'Theory of the firm: Managerial behavior, agency costs and ownership structure', Journal of Financial Economics 3(4), 305-360. https://doi.org/10.1016/0304-405X(76)90026-X

Johnston, J. \& Dinardo, J., 1997, Econometric methods, McGraw-Hill, New York.

Karadeniz, E., Kandir, S.Y., Balcilar, M. \& Onal, Y.B., 2009, 'Determinants of capital structure: Evidence from Turkish lodging companies', International Journal of Contemporary Hospitality Management 21(5), 594-609. https://doi. org/10.1108/09596110910967827

Kayo, E.K. \& Kimura, H., 2011, 'Hierarchical determinants of capital structure', Journal of Banking \& Finance 35, 358-371. https://doi.org/10.1016/j.jbankfin.2010.08.015

Kyereboah-Coleman, A., 2007, 'The determinants of capital structure of microfinance institutions in Ghana', South African Journal of Economic and Management Sciences 10(2), 270-279.

Marques, A.C. \& Fuinhas, J.A., 2012, 'Are public policies towards renewables successful? Evidence from European countries', Renewable Energy 44, 109-118. https://doi.org/10.1016/j.renene.2012.01.007

Menezes, H.C., 2003, Princípios de gestão financeira, Presença, Lisbon.

Menike, L.M., 2015, 'Capital structure and financing of small and medium-sized enterprises: Empirical evidence from a Sri Lankan survey', Journal of Small Business and Entrepreneurship Development 3(1), 54-65.

Modigliani, F. \& Miller, M.H., 1958, 'The cost of capital, corporation finance and the theory of investment', American Economic Review 48(3), 261-297.

Myers, S.C., 1977, 'Determinants of corporate borrowing', Journal of Financial Economics 5(2), 147-175. https://doi.org/10.1016/0304-405X(77)90015-0

Myers, S.C., 1984, 'The capital structure puzzle', The Journal of Finance 39(3), 575592. https://doi.org/10.2307/2327916

Myers, S.C., 1993, 'Still searching for optimal capital structure', Journal of Applied Corporate Finance 6(1), 4-14. https://doi.org/10.1111/j.1745-6622.1993. tb00369.x

Myers, S.C. \& Majluf, N., 1984, 'Corporate financing and investment decisions when firms have information that investors do not have', Journal of Financial Economics 13(2), 187-221. https://doi.org/10.1016/0304-405X(84)90023-0

Nunkoo, P.K. \& Boateng, A., 2010, 'The empirical determinants of target capital structure and adjustment to long-run target: Evidence from Canadian firms', Applied Economics Letters 17, 983-990. https://doi.org/10.1080/1744654 0802599671
Oinoa, I. \& Ukaegbu, B., 2015, 'The impact of profitability on capital structure and speed of adjustment: An empirical examination of selected firms in Nigerian Stock Exchange', Research in International Business and Finance 35, 111-121. https:// doi.org/10.1016/j.ribaf.2015.03.004

Omet, G., Al-Sharari, T., Khalaf, B. \& Yaseen, H., 2015, 'Determinants of capital structure in various circumstances: Could they be similar?', Research Journal of Business and Management 2(2), 158-168.

Onaolapo, A.A. \& Kajola, S.O., 2010, 'Capital structure and firm performance: Evidence from Nigeria', European Journal of Economics, Finance and Administrative Sciences 25, 71-82.

Parsons, C. \& Titman, S., 2008, 'Empirical capital structure: A review', Foundations and Trends in Finance 3(1), 1-93. https://doi.org/10.1561/0500000018

Petersen, M.A., 2009, 'Estimating standard errors in finance panel data sets: Comparing approaches', The Review of Financial Studies 22(1), 435-480. https:// doi.org/10.1093/rfs/hhn053

Psillaki, M. \& Daskalakis, N., 2009, 'Are the determinants of capital structure country or firm specific?' Small Business Economics 33, 319-333. https://doi.org/10.1007/ s11187-008-9103-4

Rebelo, S., 2006, 'Determinates da estrutura de capital das empresas de tecnologia de informação', dos Algarves 14, 26-31.

Rocca, M.L., Rocca, T.L., Gerace, D. \& Smark, C., 2009, 'Effect of diversification on capital structure', Accounting and Finance 49(4), 799-826. https://doi. org/10.1111/j.1467-629X.2009.00304.x

Saito, R. \& Hiramoto, E., 2010, 'Foreign activity effects and capital structure: Brazilian evidence', Revista Latinoamericana de Administración 45, 59-75.

Santos, M.S., Moreira, A.C. \& Vieira, E., 2013, Blockholders presence, identity and institutional context. Are they relevant for firm value?' International Journal of Business Governance and Ethics 8(1), 18-49. https://doi.org/10.1504/ IJBGE.2013.052740

Santos, M.S., Moreira, A.C. \& Vieira, E., 2014, 'Ownership concentration, contestability, family firms, and capital structure', Journal of Management and Governance 18(4), 1063-1107. https://doi.org/10.1007/s10997-013-9272-7

Santos, M.S., Moreira, A.C. \& Vieira, E., 2015, 'Governance with complex structures: Evidence from Western European countries', Journal of Business Economics and Management 16(3), 542-557. https://doi.org/10.3846/16111699.2013.772915

Sbeiti, W., 2010, 'The determinants of capital structure: Evidence from the GCC countries', International Research Journal of Finance and Economics 47, 56-82.

Serrasqueiro, Z. \& Nunes, P.M., 2010, 'Are trade-off and pecking order theories mutually exclusive in explaining capital structure decisions?', African Journal of Business Management 4(11), 2216-2230. https://doi.org/10.1108/14757700910934238

Serrasqueiro, Z. \& Rogão, M.C., 2009, 'Capital structure
companies', Review of Accounting and Finance 8(1), 54-75.

ilva, E.S. \& Queirós, M., 2009, Gestão financeira - Análise de investimento, Vida Económica, Porto.

Tahir, M.S. \& Alifiah, M.N., 2015, 'Corporate cash holding behavior and financial environment: A critical review', International Journal of Economics and Financial Issues 5(Special Issue), 277-280.

Titman, S. \& Wessels, R., 1988, 'The determinants of capital structure choice', The Journal of Finance 43(1), 1-19. https://doi.org/10.1111/j.1540-6261.1988.tb02585.x

Wooldridge, J.M., 2010, Econometric analysis of cross section and panel data, MIT Press, Boston, MA 


\section{Appendix 1}

TABLE 1-A1: Summary statistics.

\begin{tabular}{|c|c|c|c|c|c|}
\hline Variable & Observations & Mean & Standard deviation & Minimum & Maximum \\
\hline Leverage_ratio & 104 & 1.099187 & 3.391286 & 0.1881 & 35.2465 \\
\hline Asset_structure & 104 & 0.3917452 & 0.2297208 & 0.0093 & 0.8718 \\
\hline Age & 102 & 47.97059 & 30.07629 & 1 & 110 \\
\hline Liquidity & 104 & 2.22868 & 6.71436 & 0.0019 & 50.2408 \\
\hline Intangible_activity_level & 100 & $6.73 E+08$ & $2.06 E+09$ & 0 & $1.02 \mathrm{E}+10$ \\
\hline Return_on_sales & 88 & 4.648626 & 22.63219 & -4.9775 & 179.7684 \\
\hline Return_on_assets & 104 & 2.504371 & 2.539035 & -0.0243 & 11.5703 \\
\hline Tangibility & 104 & 0.1914587 & 0.113603 & 0.014 & 0.4168 \\
\hline Non-debt_tax_shields & 104 & 0.4322817 & 3.817053 & 0 & 38.9781 \\
\hline
\end{tabular}

